\title{
HUMAN RESOURCES AND COMPETITIVENESS OF THE TERRITORY
}

\author{
[L’udské zdroje a konkurencieschopnost' územia] \\ Anna Vaňová ${ }^{1}$, Janka Š́rová $^{2}$, Mária Seková $^{3}$ \\ ${ }^{1}$ Matej Bel University, Faculty of Economics, Tajovského 10, 97590 Banská Bystrica \\ Email:anna.vanova@umb.sk \\ ${ }^{2}$ Matej Bel University, Faculty of Economics, Tajovského 10, 97590 Banská Bystrica \\ Email:janka.sure@gmail.com \\ ${ }^{3}$ Matej Bel University, Faculty of Economics, Tajovského 10, 97590 Banská Bystrica \\ Email:maria.sekova@umb.sk
}

\begin{abstract}
The aim of the paper is to point out the importance of human resources, especially creative ones, for the competitive development of the territory. In a globalizing world at the beginning of the 21 st century, competitiveness is an indispensable precondition for sustainable land development. Within the framework of competitiveness, the soft and hard factors of the development of the territory are decisive, with a key role played by human resources with innate skills, creativity and talent. Human resources are characterized by flexibility and high migration rates. On the other hand, there are areas for sustainable development that are essential to attract and stabilize high-quality human resources. In this paperwork we present the lessons learned from the study of domestic and foreign scientific resources, own research and empiricism. Primary research collected unique data from Slovakia. On this basis, we identified human resource quality indicators and through quantitative research, we compared territorial disparities of selected indicators to help validate existing theories where creativity and talent are a significant endogenous source of competitive advantage for the territory. At the end of the paperwork, we identified the hard and soft factors that regions should prefer in strategic documents for competitiveness.
\end{abstract}

Keywords: competitiveness, competitive advantage, creative capital, creative people, creative potential, endogenous factors, region, region development, Slovakia.

JEL classification: R19

Received: 5.10.2018; Reviewed: 1.11.2018; 1.11.2018; Accepted: 6.3.2019

\section{Introduction}

The issue of competitiveness and competitive advantage is currently very actual. The process of globalization puts pressure on competitiveness in all areas of economic and non-economic life. Creation and existence of a place competitive advantage influences the economic, social or demographic structure of the territory, its development and sustainability.

The issue of competitive advantage at enterprise level or at national level is relatively well developed in both domestic and foreign literature. Less attention has so far been devoted to the competitive advantage at the level of regions, municipalities and towns, since exploration requires a multidisciplinary approach and often lack the statistical data necessary for the evaluation. One of the most important factors of place competitive advantage are human resources. Human resources are all entities located on the territory, primarily residents, entrepreneurs, investors and employees of different organizations.

Nowadays, according to various research, the most important are human resources, referred to as creative people. The essential characteristics of creative people inherently include talent, 
creativity and innate abilities of individuals - talent. Creative people take the talent with them wherever they go. Their specific feature are flexibility and migration. On the other hand, there are territories, regions whose competitive advantage is good human capital (knowledge, skills, personality, creativity, value attitudes, development potential, motivation, energy) - its bearers and sole owners are people. Therefore, the role of the territory is to stabilize or attract good people and thus ensure sustainable development.

The aim of the paper is to examine and re-evaluate the knowledge of creative human resources on the basis of a comparison of domestic and foreign research and their significance for the competitiveness of the territory and to identify the factors of the area's competitiveness that would continually create an attractive territory for the needs of creative human resources.

The aim of the paperwork is subordinated to the structure of the paperwork. The object of research is NUTS 3 territory and the subject of the survey is that human resources are primarily creative and competitive in the area. In the theoretical part of the contribution, we define basic concepts and factors of competitiveness of the territory and human resources. In the empirical part, we define the basic concepts and relations related to the issue of creative human resources, the results of our research focused on creative human resources in the regions of the Slovak Republic and foreign research focused on the migration of creative human resources.

\section{Human resources as a competitive advantage of the territory}

The issue of competitive advantage is closely linked to the concepts of competition and competitiveness, with a strong link between competitive advantage and competitiveness. The complexity of competitiveness or competitive advantage in the territory involves the microeconomic (through enterprises located in the territory) and the macroeconomic level primarily in the sense of decisions of regulations and policies implemented at the macro and microeconomic level.

In theory, it is possible to meet three kinds of advantages that the entity acquires against its competitors: a comparative advantage, a competitive advantage and a created advantage. The competitive advantage is based on Porter's work and the diamond's key factors. There are three basic approaches to a competitive advantage (Borsekova 2012).

Market-oriented competitive advantage approach (Porter 1985, Vaňová 2006, Kotler 1992, etc.), the approach of the competitive advantage based on resources (Barney 1997; Stewart 2008, etc.) and marketing oriented approach of the competitive advantage (Porter 1985, 1999; Kotler, Armstrong 1992; etc.). Market-based approach to competitive advantage focuses on costs and differentiation, with the use of mainly external factors. A competitive advantage based on resources due mainly internal resources of the territory. If a territory has unique resources, it helps create a unique market position.

The competitive advantage of the territory means a significant advantage, based on exceptional capacity in terms of quality or quantity, or the use of the potential of the territory which the territory has over its competitors and which allows it to realize more value than competition in the same market (Vaňová 2006). The survey experts identified the quality of human resources innovation and the innovative potential and creative potential of the territory as the most important factors of competitive advantage (Borseková et al. 2012, 2015).

The following graph shows the average order of importance of competitive advantage factors according to the Friedman test. 
Figure 1: Average order of importance of factors of competitive advantage

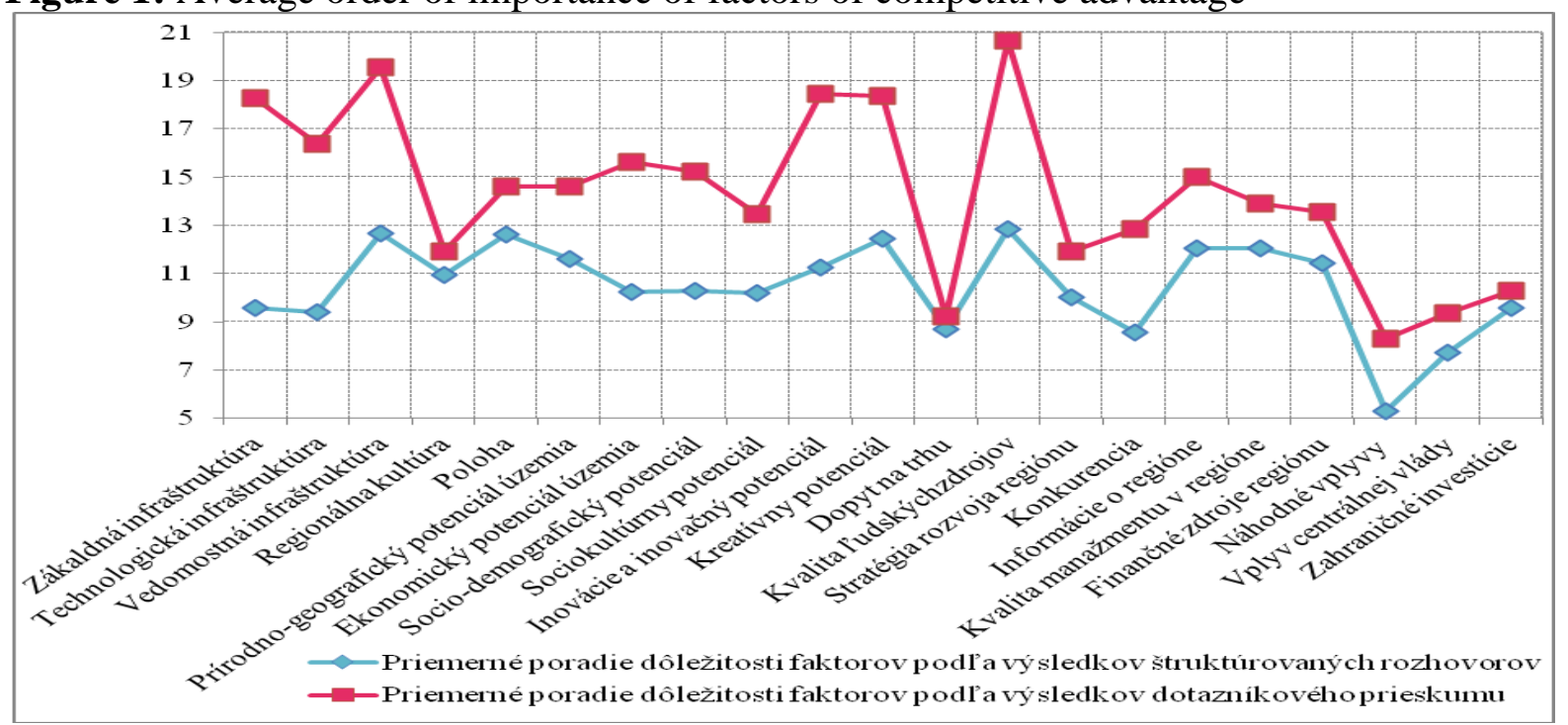

Source: Borseková 2012

Comparing the importance of factors of the competitive advantage of the region based on the results of the questionnaire survey and structured interviews using the Friedman test, statistics showed that expert groups from all Slovak regions consider the quality of human resources as their most important factor with their skills, knowledge and experience. In the second place, the knowledge factor also placed factors for innovation and innovation potential, creative potential and basic infrastructure (Borsekova 2012) in second place within the framework of the questionnaire survey. Human resources are the factor of the competitiveness of the territory, which also affects other factors of the competitive advantage of the territory like knowledgebased infrastructure, creative potential and creativity, socio-demographic potential. It follows that especially creative capital, whether human or material, plays an important role in the competitiveness of the territory. According to Vaňová (Kloudová 2010, p. 67.) creative people, thanks to their talent and abilities, have more innovated ideas, what help him to start new businesses or set up new businesses, and this is support for place development. In significant literature, entrepreneurship is considered to be one of the factors of economic development and it is the result of the use of creative capital.

\section{Aim, methodology and material}

The aim of our extensive and multi-annual research is to provide a comprehensive approach to the concept of creative people. For research processing needs, it is necessary to define and compare the categorization of creative people to quantify their presence in the studied territory of the Slovak Republic and to examine the creative potential of human resources for the development of the territory.

In order to understand the vast issue of the importance of creative people for the development of the territory, we divided the research into three phases. In the first phase of the research we defined the concept of creative human resources and based on the collection of original data, we compared the situation in the Slovak Republic with the existing concepts of the concept of creative people. In the second phase of the research, we analyzed the reasons for the migration of creative people using the analysis and comparison of already existing research in the Nordic countries of the EU (Hansen and Niedomysl 2009) and research into the internal migration of the population in the Slovak Republic (Šprocha 2011). In the third phase of the research we are engaged in modeling the index of human capital creativity in the chosen territory. This method 
is based on input and output, where inputs are quality human resources and outputs are innovation, entrepreneurship (Stimson et al. 2011) and intellectual property (Howkins 2001). When designing the model, we process the primary data obtained from the own survey of the databases of the Industrial Property Office of the Slovak Statistical Office of the Statistical Office of the Slovak Republic and the statistical survey "Innovation activity of Slovak enterprises".

In the paper we present a selected part of our empirical research from the first and second phases of unique and extensive scientific observation. In the processing of the contribution, we used the research of secondary data and sources from domestic and foreign scientific researches, literature and primary data obtained from own database research, state and regional strategies, Population census, home and housing censuses 2011, statistical surveys. Secondary data on creative inhabitants allowed us to quantify and compare differences in NUTS 3 regions within the Slovak Republic.

When defined the notion of creative class, creative people, creative human resources, factors of creative environment development, we have reviewed the international classifications, the classifications given in the EU documents and the formulated definitions in the SR management documents. In European and American studies, the ISCO 08 classification of employment is defined in the definition of people working in the creative industries, which is a classification of jobs established by an international organization (ILO). The applied ESPON research program defines a creative workforce based on professions not in ISCO 88 4D. In order to identify creative people in NUTS 3 regions, we used only the most comprehensive and exhaustive data from the Census, Home and Housing (SODB 2011).

In selecting the creative industries, we were inspired by a domestic empirical study (Ira, Garitan 2014) and selected 12 creative activities according to SK NACE: 60 - radio and television broadcasting activities, 59 - film, video and television programming, 90 - creative , 58 publishing, 73 - advertising and market research, 18 - printing and reproduction of recording media, 72 - scientific research and development, 63 - information services, 62 - computer programming, consultancy and related services, architectural and engineering activities, 74 other professional, scientific and technical activities, 91 - activities of libraries, archives, museums and other cultural facilities.

We evaluated the data using descriptive statistics - the method of dependency analysis (correlation analysis), the classification method (variation coefficient). In the second and third phase of the research, data will be analyzed using Hierarchical Cluster Analysis (Král', Koróny 2011). This shall improve the clarity of the dataset for further interpretation. The problem will be further examined by Principal Component Analysis to study possible correlated variables (Král', Koróny 2011). The obtained unique statistics on creative capital will be evaluated by TOPSIS method (Technique for Order Preference by Similarity to Ideal Solution). This will enable to determine the rank of Regions and to identify the variant with nearly ideal value.

\section{Creative Human Resources in conditions of Slovakia}

Creative people are the important part of human resources. In the next part we will focus on the identification and quantification of creative people in the territory of the Slovak Republic. The selection of indicators for their identification is based on empirical research at home and abroad where authors, while exploring the creative environment and the quality of human capital, considered talent, creativity and the use of new technologies to be important. From the point of view of the creative economy, creative people are characterized as people working in the 
creative industries (Florida 2002), people with university education (Hansen 2007), people with the ability to work with the Internet (Ira, Garitan 2014). In the next part of the paperwork, we will notice how migration is affecting the distribution of creative people in Slovakia (Šprocha 2011).

When selecting statistical data for our research, we took into account the European study by Boschma and Fritsch (2009), the applied ESPON (European Spatial Planning Monitoring Network) and Domestic Empirical Study (Ira and Garitan 2014) which highlights the specific position of Bratislava within Slovak Republic. In the analysis, in the first phase of the survey, the only available relevant data was obtained from the Census of Population, Homes and Apartments (SODB) 2011, data on internal migration from internal migration from the SO SR (in the research that we are currently implementing, data collection is being carried out by primary research because the SO of the SR does not register the data necessary for our research).

In the analysis, we focused on the evaluation of the indicators that characterize and define creative people: the share of creative people (KEA) in selected sectors of the economically active population (EA), the share of the tertiary educated population (VS) from the living population (TBO), the share of the people with the computer knowledge (PC) from the living population (TBO), the share of inhabitants representing Bohemians (Bohemians are represented exclusively in artistic professions and play an important role in attracting other creative people) from the creative population in selected creative industries (Table 1).

Table 1: The status of Slovak regions according to selected indicators of creative people

\begin{tabular}{|c|c|c|c|c|}
\hline Region & $\begin{array}{c}\text { share KEA from } \\
\text { EA }\end{array}$ & share VŠ from TBO & share PC-1 from TBO & $\begin{array}{c}\text { share Bohemians from } \\
\text { KEA }\end{array}$ \\
\hline BA & 9.20 & 26.17 & 66.05 & 6.99 \\
\hline TT & 3.63 & 11.50 & 54.32 & 5.23 \\
\hline TN & 3.04 & 12.51 & 54.47 & 4.65 \\
\hline NR & 3.44 & 11.99 & 53.10 & 6.10 \\
\hline ZA & 3.69 & 12.96 & 56.41 & 4.74 \\
\hline BB & 3.71 & 12.33 & 49.56 & 5.87 \\
\hline PO & 3.01 & 11.70 & 51.06 & 6.32 \\
\hline KE & 3.86 & 13.06 & 48.53 & 6.06 \\
\hline Slovakia & 4.19 & 14.03 & 54.19 & 5.74 \\
\hline
\end{tabular}

Legend:

BA Bratislava region

TT Trnava region

NR Nitra region

ZA Zilina region

Source: own processing based on data from SODB ŠÚ SR 2011
BB Banska Bystrica region

PO Presov region

KE košický region

Data on the representation of creative people in the individual regions of Slovak Republic shows the dominant position of Bratislava Region, where $9.20 \%$ of the economically active population is working in the creative sectors. The share of people working in the creative industries in Bratislava Region is 3 times higher than the share of people working in creative industries in other regions of Slovak Republic.

An important indicator of creative people in the surveyed territory is the share of higher educated people from the total population. Higher-educated people represent creative people (Hansen and Niedomysl 2009) because the correlation between higher education and belonging 
to the creative population is high (the correlation coefficient in the Nordic countries is 0.94). The share of university-educated people in the SR was 14.03\% in 2011, dominating Bratislava Region whose UNI population is $26.17 \%$. The distribution of representation of the UNI population in the lagging areas of Slovak Republic is equal and represents values from 11,50\% in Trnava region to $13,06 \%$ in Košice region.

Within the indicator "Working with the Internet as a part of computer knowledge", average in Slovakia is $54.19 \%$, with above average values of this indicator in Bratislava Region. In the focused areas of Slovak Republic this indicator oscillates around the average.

The Bohemians share of all people working in the creative industries is an interesting analysis result. People characterized as Bohemians represented 5.74\% from the average of Slovak population and $4.19 \%$ of the population working in the creative industries. In the case of Bratislava region, Nitra region, Prešov region, Košice region and Banská Bystrica region, the value of a given indicator (the Bohemians share) is higher than the national average. This indicator along with the Florida statement (Bohemians plays an important role in acquiring other creative categories and are a sign of urban cultural tolerance) suggests potential for the development of appropriate strategies to attract and stabilize creative people in lagging areas (Florida 2002).

For the measurement of regional disparities, we use the coefficient of variation that is suitable for comparison and is not dependent on the magnitude of the measured values (Ira, Garitan 2014, p. 201) and is suitable for measuring various variables (Hamada 2012).

The variation coefficient (Vk) is given in percent age and expresses how many of the arithmetic mean value represents the standard deviation. The higher is the value, the greater the variability of the given set (Hamada 2012).

$$
\mathrm{Vk}=\frac{\mathrm{Sx}}{\bar{x}} 100 \%
$$

Sx - standart deviation

$\bar{x}$ - average

When comparing the four selected indicators in the regions, we can see from the analysis that inequalities in the representation of the creative population $(0.46)$ and the university educated population $(0.33)$ are seen as the most significant inequalities. The smallest territorial inequalities can be observed in the share of people with computer skills (tab.2).

Based on the previous results of the analysis of the representation of creative people in the regions of the Slovak Republic and the dominant position of the Bratislava region, we decided to examine the different dependencies of the variables on two levels:

1. Correlation analysis of data for all regions of the SR

2. Correlation analysis of data excluding Bratislava region 
Table 2: Territorial disparities of selected indicators

\begin{tabular}{|c|c|c|c|c|}
\hline Region & $\begin{array}{c}\text { EAare KEA from } \\
\text { EA }\end{array}$ & share VŠ from TBO & share PC-1 from TBO & $\begin{array}{c}\text { share Bohemians from } \\
\text { KEA }\end{array}$ \\
\hline BA & 9.20 & 26.17 & 66.05 & 6.99 \\
\hline TT & 3.63 & 11.50 & 54.32 & 5.23 \\
\hline TN & 3.04 & 12.51 & 54.47 & 4.65 \\
\hline NR & 3.44 & 11.99 & 53.10 & 6.10 \\
\hline ZA & 3.69 & 12.96 & 56.41 & 4.74 \\
\hline BB & 3.71 & 12.33 & 49.56 & 5.87 \\
\hline PO & 3.01 & 11.70 & 51.06 & 6.32 \\
\hline KE & 3.86 & 13.06 & 48.53 & 5.06 \\
\hline Slovakia & 4.19 & 14.03 & 54.19 & 0.760114149 \\
\hline & & & & 5.744479524 \\
\hline Stand.deviation $=$ & 1.913502956 & 4.619750498 & 5.126710771 & \\
\hline average $=$ & 4.194688083 & 14.02794046 & 54.1877499 & 0.132320804 \\
\hline
\end{tabular}

Source: own processing based on data from SODB ŠÚ SR 2011

From the research results (Table 3), we observe the strong direct positive relationship between the university educated population and those working in the creative industries, with a correlation coefficient of 0.958, which is confirmed by the 2009 research in Sweden (0.94). We also see a strong direct positive relationship between the size of the creative population and the number of Bohemians. This relationship confirms expression of the ability of Bohemians to attract creative people (Florida, 2002).

Table 3: Relationship between KEA and selected indicators for all regions of the SR

\begin{tabular}{|c|c|c|c|c|c|c|c|c|}
\hline & & KEA & EA & VŠ & $\mathrm{TBO}$ & PC_1 & $\begin{array}{l}\text { migration } \\
\text { balance }\end{array}$ & Bohemians \\
\hline \multirow[t]{2}{*}{$\begin{array}{l}\text { Creative } \\
\text { citizens }\end{array}$} & $\begin{array}{l}\text { Pearsonov } \\
\text { koeficient }\end{array}$ & 1 & .074 & $.958^{* * *}$ & -.153 & .459 & $.852^{* * *}$ & $.993^{* *}$ \\
\hline & $\begin{array}{l}\text { p-hodnota } \\
\text { Sig. (2- } \\
\text { tailed) } \\
\text { Research } \\
\text { areas }\end{array}$ & 8 & .862 & .000 & .717 & .253 & .007 & .000 \\
\hline
\end{tabular}

Source: output from programme SPSS

The direct positive relationship between the size of the creative population and the migration balance is very interesting result of this study (Table 4). The result suggests that the creative population is drawing extra labor from the Floridian concept. (We can only use this interpretation of the analysis results for 2011. We will compare them with data for years after 2011 in the next research.)

The internal migration analysis 2011 shows that most of the regions of Slovak Republic have a negative migration balance. The highest positive migration balance is in Bratislava Region followed by the Trnava region. 
Due to the specific situation of Bratislava Region, which is due to the marked difference between the indicators monitored, we decided to repeat the analysis with the exclusion of Bratislava Region (Table 5).

Table 4: Migration balance in the Slovak Republic for 2011

\begin{tabular}{|c|r|}
\hline Region & Migration balance \\
\hline BA & 4537 \\
\hline TT & 1433 \\
\hline TN & -424 \\
\hline NR & 160 \\
\hline ZA & -150 \\
\hline BB & -676 \\
\hline PO & -1421 \\
\hline KE & -493 \\
\hline
\end{tabular}

Source: own processing based on the internal migration database of the ŠÚ SR 2011

Table 5: The relationship between KEA and selected indicators without the Bratislava Region

\begin{tabular}{|c|c|c|c|c|c|c|c|c|}
\hline & & KEA & EA & VŠ & $\mathrm{TBO}$ & PC_1 & $\begin{array}{c}\text { migration } \\
\text { balance }\end{array}$ & Bohemians \\
\hline \multirow[t]{3}{*}{$\begin{array}{l}\text { Creative } \\
\text { citizens }\end{array}$} & $\begin{array}{l}\text { Pearsonov } \\
\text { koeficient }\end{array}$ & 1 & .716 & .792 & .701 & .577 & -.235 & .888 \\
\hline & $\begin{array}{l}\text { p-hodnota Sig. } \\
\text { (2-tailed) }\end{array}$ & & .070 & .034 & .079 & .175 & .612 & .008 \\
\hline & Research areas & 7 & 7 & 7 & 7 & 7 & 7 & 7 \\
\hline
\end{tabular}

Source: output from programme SPSS

The results of the analysis in which we have set up the Bratislava Region with a dominant position in all indicators confirm the direct positive relationship between the creative population and the university educated population and Bohemian representatives. The positive relationship between the size of the creative population and the migration balance has not been confirmed in this case (correlation coefficient -0.235), the dependence is weak and statistically insignificant. Interesting is the change in the positive dependence of the indicator on the indirect dependence.

This finding is also interesting from the point of view of further research in investigating how the relationship between migration and the creative population will evolve to include statistics for 2001 and then for 2021. If the non-linear correlation between these indicators increases, we can assume that the higher migration balance means that more creative population remains in the territory outside the metropolitan city.

\section{Attractiveness of the territory for creative human resources}

Based on the knowledge of foreign scientific work and our own research on the economic benefits of creative people, we have come to realize that creative human resources are highly mobile and an important element of their localization (based on the concept of a creative economy) is an environment supporting talent and creativity (Kozáková, Miškovicová 2016). On the other hand, good human resources in the territory have the ability to attract other highquality human resources, which creates the premise of competitiveness and the sustainable development of the territory. Therefore, it is important for territory development to focus 
primarily on supporting the creation of a creative environment as well as mobilizing endogenous factors.

According to Nijkamp (2011, p. 10) is important focusing on the mobilization of endogenous factors in the planning of territorial development strategies. The author states endogenous factors in the "Pentagon model":

1. Availability of productive capital (PC) - a factor derived from neoclassical theories, where output is a determinant of labor and capital.

2. Presence of human capital (HC) - human capital (knowledge, skills, creativity).

3. Access to social capital (SC) - interaction and communication between people, socioeconomic links, social support system, business networks (formal and informal), trustbased relationships.

4. Utilization of Creative Capital (CC) - ability to respond to new challenges, opportunities, ability to use new ideas in creating new services and products. This factor can be found in a multicultural environment.

5. Existence of ecological capital (EC) - the existence of a good quality of life, the presence of green, water. But also the existence of an attractive environment (leisure opportunities - restaurants, cinemas, theaters, recreational facilities)

Creative people enjoy a wide variety of activities (e.g., traveling, antique shopping, bike riding, and running) that highlight the collective interest in being participants and not spectators (Florida 2002). They are looking for cities rich in cultural and recreational opportunities, dynamic urban life and cultural diversity. These elements form the basis of the term "quality of place". Localizing factors for creative people by the author are the existence of universities, a community of successful entrepreneurs, business angels and risky investors, the presence of bohemians, immigrants and homosexual people. Economic theories (Marshall 1920, Jacobs 1969, Porter 1990 and Rehak 2014) explain the concentration of companies in cities for better availability of suppliers, the common labor market, and the passage of knowledge. However, Florida (Rehak 2014) argues that better access to talented workers is the main reason for companies' concentration in cities. On the other hand, according to social capital theory (Putnam in Rehak 2014, p. 602), economic growth of cities is associated with communities where people and firms are linked by strong interrelationships. Unlike Florida Social Capital Theories (Rehak 2014), openness tolerance and looser relationships are a magnet for creative people.

When exploring the migration and localization of creative people, researchers in different countries deal with hard and soft localization factors. The results of the studies from Sweden (2009), based on the work of Florida (2002) and its critics Glaeser (2004), Pecka (2005), Markunsena (2006) show that work and social reasons are the main reason for localizing decisions of creative people. Marlett and van Woerkens' research results in the Netherlands (in Belvončíková, 2014) show that creative people migrate because of employment opportunities, aesthetic features (nature, historical buildings) and the traditional amenities of places (culture, cafes) named as "quality of place". According to Fritscha (2007) for creative people in Germany, a high level of ethnic diversity, cultural activities, public spending on education and health care is important. At the same time, they do not ignore the market opportunity. In the empirical studies of Markunsen and Schrock (2006), artists in the United States prefer local community and city amenities when choosing a site. Research in the Netherlands, Germany and the USA suggests and demonstrates Florida's claims (2002) that creative people are heading into a tolerant environment with a high concentration of cultural and recreational opportunities. Empirical studies in the world also deal with the policy aspect of attracting creative people to 
cities. Authors of research policies to attract creative people have used qualitative methods in case studies in the UK, Ireland, Finland, and Australia (Montgomery 2007) in Danish cities (Sorensen 2010). Based on these research, creative people are looking for an open and supportive environment that leads to their self-realization, while creative creative concentration brings new ideas, innovative solutions, and thus contributes to new products, new businesses, and the overall development of the region and its competitiveness.

Based on the above-mentioned scientific and professional literature and the results of empirical studies, we identified (Table 6) environmental factors supporting talent and creativity of creative people, which are at the same time a source of attractiveness and competitiveness of the area in its attempt to attract good human resources. For land management, it should be a priority to focus on strategic plans to develop these factors (Vaňová et al. 2016).

Table 6: Factors of attractiveness of the environment for creative human resources

\begin{tabular}{|l|c|c|}
\hline Factors of environment & soft & hard \\
\hline Work possibilities & & $\mathrm{X}$ \\
\hline traditional furnishings (cafes, restaurants, cinemas ...) & & $\mathrm{X}$ \\
\hline public costs (education and health care) & & $\mathrm{X}$ \\
\hline aesthetic features of the environment (nature, historical buildings) & $\mathrm{X}$ & \\
\hline ethnic diversity & $\mathrm{X}$ & \\
\hline Cultural activities & $\mathrm{X}$ & \\
\hline Local community & $\mathrm{X}$ & \\
\hline tolerance (gay, minority ...) & $\mathrm{X}$ & \\
\hline $\begin{array}{l}\text { personal highlights (personal trajectories - proximity of family, friends, } \\
\text { place of study, place of birth) }\end{array}$ & $\mathrm{X}$ & \\
\hline
\end{tabular}

Source: own processed according to Markunsen a Schrock (2006), Montgomery (2007), Sorensen (2010), Marlet, Woerkens (2005), Florida (2002)

\section{Conclusion}

The aim of the paper was to explore and re-evaluate the knowledge of creative human resources, their importance for the competitiveness of the territory and to identify factors of territory competitiveness for the creative human resources.

On the basis of the comparison of domestic, foreign and own research, we worked on the issue of the competitiveness of the territory and the importance of human resources in the empirical part, based on primary and secondary research, to identify creative human resources in the Slovak regions and factors of attractiveness of the competitive territory.

The results of the present work will be essential in the next phase of the research on evaluation of the regions in regards of creativity. This work is based on unique and laboriously harvested data on creative capital (innovations, intellectual property, formation of SMEs in creative sectors of industry) created by creative people. Results of the work and identification of quality human capital in considered regions will benefit determination of weighing factors for studied criteria using analytic hierarchy process and scoring method. Thanks to the methods such as Principal Component Analysis we can in the present day identify and comprehend the correlations of studied variables. Results of the comprehensive work will be published in scientific journals.

Based on our and foreign research, we can claim that human resources with their capital of creativity and talent are a significant endogenous source of the competitive advantage of the territory. Ideas and new concepts create new products, new economic values that generate new jobs. Therefore, it is important to pay attention to the issue of creative human resources. The 
Lisbon Council study (2000) highlights the stagnation of human capital in some Central and Eastern European countries due to a lack of investment in education. The study points to factors that will hamper the performance of the economy in the near future. This is mainly about unfavorable demographic trends, brain drain and insufficient investment in education. In conclusion, the authors bring recommendations for the political orientation of Central and Eastern European countries. These are recommendations such as improving public investment in education, integrating all socio-demographic groups into the modern labor market, fueling the world's knowledge networks by supporting universities, research institutes in technology and research networks in Europe, preparedness for an aging society and thus reducing negative demographic impacts. These recommendations also correspond to our findings, especially with regard to the need for the quality of education, networking and coworking of subjects in the territory.

Based on the findings of foreign scientific work and our own research on the economic benefits of creative people, we have come to realize that creative human resources are highly mobile and an important element of their localizing decision (based on the concept of a creative economy) is an environment supporting talent and creativity. On the other hand, good human resources in the territory have the ability to attract other high-quality human resources, which creates the premise of competitiveness and the sustainable development of the territory. Therefore, it is important for developmental territories to focus primarily on supporting the creation of a creative environment by mobilizing endogenous soft and hard factors.

\section{References}

[1] BARNEY, J. B., 1997. Gaining and sustaining competitive advantage. Don Mills, Ontario: Addison-Wesley Publishing Company.

[2] BELVONČÍKOVÁ, E., 2014. Prístupy ku skúmaniu kreatívnej ekonomiky v empirických štúdiách. 16 -31 s. [vid. 20. máj 2017] Regionální disparity. Ostrava: Ekonomická fakulta VŠB - TU Ostrava, cop.2007-2014. ISSN 1802-9450. Dostupné na internete: http://disparity.idealnihosting.cz/cz/elektronicky-casopis/

[3] BOSCHMA, R. and M. FRITSCH, 2009. Creative class and Regional growth: empirical evidence from seven european countries, Clark University: Journal Economic Geography, Volume 85 - Issue 4, s. 391 - 423

[4] BORSEKOVÁ, K., 2012. Identification and exploitation of the competitive advantage on the regional level (PhD thesis). Banská Bystrica - EF UMB. 2012.

[5] BORSEKOVÁ, K., K. VITÁLIŠOVÁ and A. VAŇOVÁ, 2015. From tourism space to a unique tourism place through a conceptual approach to building a competitive advantage. In Marketing places and spaces: advances in culture, tourism and hospitality research / ed. Antónia Correia, Juergen Gnoth, Metin Kozak, Alan Fyall. Vol. 10., 1. vyd. Bingley: Emerald Group Publishing Limited, Pp. 155-172 2015. ISBN 978-1-78441-940-0.

[6] FLORIDA, R., 2002. Rise of the creative class: and how it's transforming work, leisure, community, \& everyday life. New York: Basic Books. 2002 ISBN 0465024777.

[7] HAMADA, R., Vybrané spôsoby a metódy merania a hodnotenia regionálnych disparit, Praha: Vysoká škola regionálniho rozvoje, [vid. 10. júl 2017]. ISSN 1805-3246. Dostupné na internete: http://www.regionalnirozvoj.eu/201401/vybrane-sposoby-metody-meraniahodnotenia-regionalnych-disparit 
[8] HANSEN, H. and T. NIEDOMYSL, 2009. Migration of the creative class: evidence from Sweden. Journal of Economy Geography, Volume 9, Issue 2, 1 March 2009, Pages 191206. ISSN 1468-2710

[9] HOWKINS, J., 2002. The creative economy. The creative economy : how people make money from ideas. London : Penguin Books, 2002. 269 s. ISBN 978-0-140-28794-3.

[10] IRA, V. a M. GARITAN, 2014. Ekonomická aktivita v tvorivých odvetviach: Postavenie Bratislavyv rámci Slovenska a vnútromestské rozdiely, 197 - 209 s.[vid. 20. máj 2018] ISSN: 1210-3519 Dostupné na: https://www.sav.sk/index.php?lang=sk\&doc=journal-list

[11] KLOUDOVÁ, J. a kolektív, 2010. Kreatívni ekonomika - Trendy, výzvy, přiležitosti, Grada Publishing, a.s., 2010, ISBN 978-80-247-3608-2

[12] KORÓNY, S. a P. KRÁL, 2011. Štatistické metódy pre prírodné vedy, 2011, Banská Bystrica: Ekonomická fakulta UMB, ISBN 978-80-557-0344-2

[13] KOTLER, P., 1992. Marketing Management. Praha: Victoria Publishing, 1992. ISBN 8085605-08-2

[14] MARKUSEN, A., 2006. Urban development and the politics of a creative class: evi-dence from the study of artists., Environment and Planning A, [online].10. January, 2006, 19211940 s. [vid. 20. november 2017] Dostupné na internete: http://journals.sagepub.com/toc/epna/38/10

[15] MONTGOMERY, J., 2007. Creative industry business incubators and managed workspaces: A review of best practise, Taylor and Francis online, 2007, $601-617$ s. ISSN 0269-7459

[16] PORTER, M. E., 1985. Konkurenční výhoda. Praha: Victoria Publishing, 1992. 626 s. ISBN 80-85605-12-0

[17] PORTER, M. E., 1999. Competitive Advantage of Nations. Free Press, 1998. 896 s. ISBN 0684841479

[18] REHÁK, Š., 2014: Kreatívna trieda a kreatívne mestá. Teoretický koncept a jeho limity Sociológia - Slovak Sociological Review, [online] 2014, 599-619 s. [vid. 10. jún 2017]. ISSN 1336-8613 Dostupné na internete: https://www.sav.sk/index.php?lang=sk\&doc=journallist\&part=list_articles\&journal_issue_no=11113541

[19] SORENSEN, F., L. FUGLSANG and J. SUNDBO, 2010. Experience economy, creative class and business development in small Danish towns, Taylor and Francis online, 2010, 177 - 202 s. ISSN 1753-5069

[20] STEWART, H., 2005. Some important distinctions in place branding. In: Place Branding. 2005. Ročník 1. Číslo 2. s.116-121. ISSN 1744-070X

[21] STIMSON, R., R. STOUGH and P. NIJKAMP, 2011. Endogenous Regional Development, Edward Elgar Publishing, Inc., 2011, ISBN 978-1-84980-456-1

[22] ŠPROCHA, B., Vnútorná migrácia osôb s vysokoškolským vzdelaním do 35 rokov, 2011, Prognostické práce SAV,3, 2011, č.4 [online] 299 - 322, [vid. 13.4.2015]. Dostupné na internete: http://www.prog.sav.sk/archive-forecasting-work

[23] ŠTATISTICKÝ ÚRAD SR 2011. Sčítanie obyvatel'ov, domov a bytov. [online]. [vid. 20. jún 2017]. Dostupné na: https://census2011.statistics.sk/ 
[24] VAŇOVÁ, A., 2006. Strategické marketingové plánovanie rozvoja územia. Banská Bystrica: Ekonomická fakulta UMB, 2006. 140 s. ISBN 80-8083-301-X

[25] VAŇOVÁ, A., 2010. Kreatívna ekonomika a rozvoj územia (z pohl'adu marketingu územia) In Kloudová a kol. Kreativni ekonomika : vybrané ekonomické, právní, masmédiální a informatizační aspekty / rec. Ján Svák, Milan Mikulaštík, František Ochrana. 1. vyd. Bratislava : Eurokódex, 2010, s. 59-84, ISBN 978-80-89447-20-6

[26] VAŇOVÁ, A., K. BORSEKOVÁ, D. A. COLE, J. NEMEC, A. MIŠKOVIČOVÁ a K. VITÁLIŠOVÁ, 2016. Kreatívne odvetvia ako zdroj nehmotných aktív v kontexte inteligentného rozvoja a inovácí́. 1. vyd. - Banská Bystrica: Vydavatel'stvo Univerzity Mateja Bela - Belianum, 2016. ISBN 978-80-557-1173-7 